\title{
EXPERIMENTAL AND NUMERICAL ANALYSIS OF COMPRESSION THIN-WALLED COMPOSITE PLATES WEAKENED BY CUT-OUTS
}

\begin{abstract}
K. FALKOWICZ ${ }^{1}$
Buckling and postbuckling response of thin-walled composite plates investigated experimentally and determinated analytically and numerically is compared. Real dimension specimens of composite plates weakened by cut-out subjected to uniform compression in laboratory buckling tests have been modelled in the finite element method and examined analytically based on $\mathrm{P}-\mathrm{w}^{2}$ and $\mathrm{P}-\mathrm{w}^{3}$ methods. All results were obtained during the experimental investigations and the numerical FEM analysis of a thin-walled composite plate made of a carbon-epoxy laminate with a symmetrical eight-layer arrangement of $[90 /-45 / 45 / 0]_{\mathrm{s}}$. The instrument used for this purpose was a numerical ABAQUS ${ }^{\circledR}$ program.
\end{abstract}

Keywords: thin-walled structure, buckling load, postbuckling, composite, experimental investigations, FEM, numerical analysis, plate with cut-out

\section{INTRODUCTION}

Thin-walled structures made of composite materials are used in different branches of industry due to very good proper strength and stiffness indicators in relation to their own weight. Thanks to these features, they are widely used in the sports and automotive industries, aerospace engineering, and civil engineering, causing more and more designers to reach for lightweight materials in the design of building structures [24]. For example, in civil engineering, composite materials are used to reinforce concrete [23], building construction, and even windows and doors. Another example of application are shovels in wind turbines [27] and various kinds of crane girders. One of the most

\footnotetext{
${ }^{1}$ MSc Eng., Lublin University of Technology, Faculty of Mechanical Engineering, Nadbystrzycka 36, 20-618 Lublin, Poland, e-mail: k.falkowicz@pollub.pl
} 
important features of structures made of thin-walled composites is stability $[15,25]$. This structure can lose of stability even under operational load $[10,26]$, but when the buckling of a thin-walled element is local and elastic, the structure can be safely operated in the post-critical state $[2,11,21$, $26]$. Therefore, to improve the carrying capacity of this type of construction, and even be encouraged to use of this type thin-walled structures as load-bearing elements or as elastic elements, it is proposed to improve their load capacity, by forced the work of construction according to a higher flexuraltorsional form of buckling. This can be done by making a notch in the centre of the plate and initiating the displacement in an opposite direction of the vertical stripes produced in the plate. Issues of stability, critical behavior, and limit load capacity of plates with holes are described, among others, in $[8,12,17]$.

Design of machines and devices sometimes requires the use of elements that will protect them from damage. Such elements should have low weight and specific operating characteristics. Apart from that, machine design often requires the use of elastic elements that need to be built in a rectangular space. In either cases, plates with cut-outs can be applied.

The investigation involved the original concept of a thin-walled plate element with a central cut-out for use as a spring element. Research included linear and nonlinear numerical analysis of stability (FEM) of the thin-walled, carbon-epoxy composite plate under axial compression and the experimental validation of the results.

\section{SUBJECT AND SCOPE OF RESEARCH}

A numerical analysis and experiment were performed on a thin-walled composite plate with a central rectangular cut-out under compression. The specimen had the following dimensions (width $\mathrm{x}$ height $\mathrm{x}$ thickness of the wall): $160 \times 80 \times 1.048 \mathrm{~mm}$ and a symmetrical cut-out in the middle measuring about: height $a=100 \mathrm{~mm}$ and width $b=30 \mathrm{~mm}$. To reduce the effect of stress concentration, indentations were made on the loaded edges. The material from which plate was made, had an 8-layer CFRP laminate. The layers had the same thickness - $0.131 \mathrm{~mm}$ - in a symmetric system of layers with respect to the median plane of the composite. The subjects of the research were made of M12/35\%/UD134/AS7/300 Hexcel's "HexPly" unidirectional carbon-epoxy composite prepreg tape. Its matrix was made of epoxy resin (mass density: $1.24 \mathrm{~g} / \mathrm{cm} 3$; $\mathrm{Tg}: 128^{\circ} \mathrm{C}$; Rm: $64 \mathrm{MPa}$; v: 0.4; E: $5.1 \mathrm{GPa}$ ), whereas the reinforcement was AS7J12K carbon fibers (mass density: $2.5 \mathrm{~g} / \mathrm{cm} 3 ; \mathrm{Rm}: 4830$ MPa; v: 0.269; E: $241 \mathrm{GPa}$ ). The nominal volume fraction of reinforcing fibers in the composite was ca $60 \%$. The composites were produced through an autoclaving technique in the Department of 
Material Engineering at the Lublin University of Technology $[3,18]$. The material properties of the chosen composite materials are as follows:

- Tensile moduli: $\mathrm{E}_{1}=131.71 \mathrm{GPa}, \mathrm{E}_{2}=6.36 \mathrm{GPa}$;

- Shear modulus: $\mathrm{G}_{12}=4.18 \mathrm{GPa}$;

- Poisson's ratio: $\mathrm{v}_{12}=0.32$;

- Tensile strengths: $\mathrm{F}_{\mathrm{TU} 1}=1867 \mathrm{MPa}, \mathrm{F}_{\mathrm{TU} 2}=26 \mathrm{MPa}$;

- Compression strengths: $\mathrm{F}_{\mathrm{CU} 1}=1531 \mathrm{MPa}, \mathrm{F}_{\mathrm{CU} 2}=214 \mathrm{MPa}$;

- Shear strength: $\mathrm{F}_{\mathrm{SU}}=100.15 \mathrm{MPa}$.

Geometric diagram of the plate weakened by cut-out is shown in Fig.1.

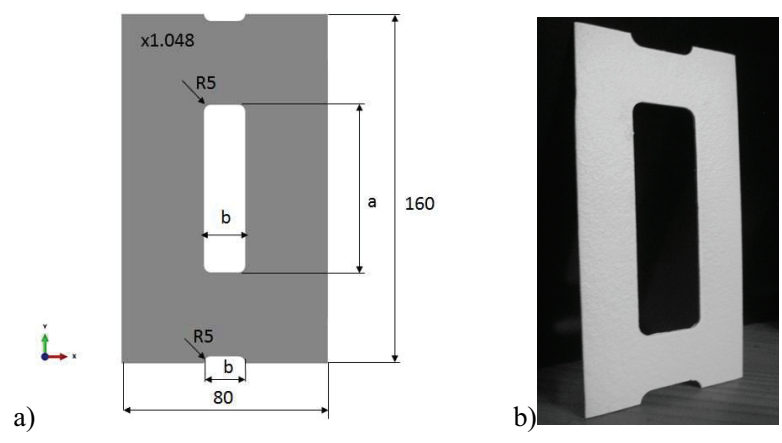

Fig. 1. Thin-walled plate: a) geometric model, b) physical model

Different layer arrangements were tested, but the discussion of the methods of buckling load determination was conducted for one lay-up case, i.e. [90/-45/45/0]s.

\section{NUMERICAL CALCULATIONS}

The buckling and postbuckling behaviour was analysed using the finite element method (FEM) with commercial software ABAQUS ${ }^{\circledR}[1]$. The linear buckling analysis and geometrical nonlinear problems were solved. First, the linear buckling analysis was carried out to find the buckling load and the corresponding buckling mode. The second stage of the calculations was the solution of the problem of nonlinear stability, in which calculations were carried out on the model with geometric imperfections corresponding to a flexural-torsional form of buckling of a structure. Then, a nonlinear analysis was performed. A higher buckling mode was used as the initial geometric 
imperfection with amplitude corresponding to 0.1 of the analysis plate wall thickness. The maximal compression load applied in the nonlinear analysis was approximately 3 times higher than the lowest buckling load. This enabled determination of the post-critical equilibrium path of the structure describing the relationship between the load and plate displacement $\left(\mathrm{P}-\mathrm{U}_{3}\right)$ for a weakly post-critical range. The geometrically nonlinear problem was solved by the Newton-Raphson method [1, 4, 5, 14, 16, 22].

The numerical model presented in Fig.2b was discretized using an eight-node, multi-layered shell element with six degrees of freedom at each node, with a reduced integration of S8R and using filtering of "parasitic forms". On the basis of earlier research [9-11], it was decided to discretize the geometrical model in such a way as to obtain 4500 finite elements and 14012 nodes.

a)

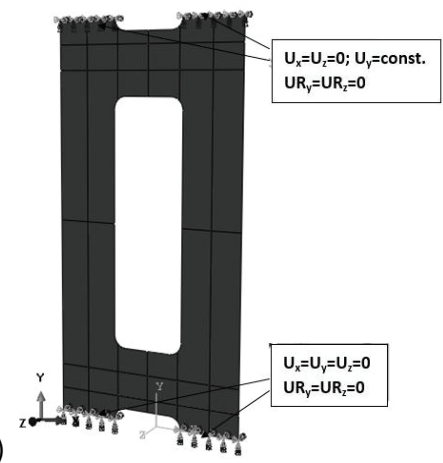

b)

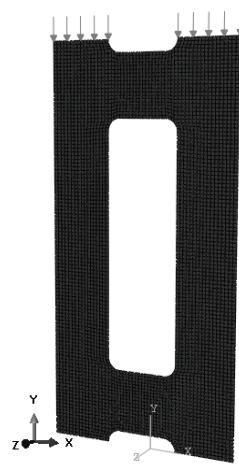

Fig. 2. Discrete model of a composite plate a) boundary conditions, b) discretization of the geometric model

In the developed numerical model, the material is assigned orthotropic properties in a flat state of stress. In order to determine the strength of the composite used the tensor failure criterion - Tsai-Wu, dedicated for composite materials. The boundary conditions formulated for the numerical model ensured articulated support of the compressed composite plate - Fig.2a. Displacement of the nodes belonging to the lower edge for the vertical direction has been blocked. The load of the model was realized by loading the upper edge of the plate to provide uniform compression to the vertical direction.

\section{EXPERIMENT}

All experimental tests were performed on a universal Zwick/Roell Z050 testing machine with specially designed grips ensuring articulate support. The experiments were performed at room 
temperature with a constant velocity of a cross-bar of the machine, equal to $2 \mathrm{~mm} / \mathrm{min}$. The test stand for compression tests with mounted grips is presented in Fig.3.

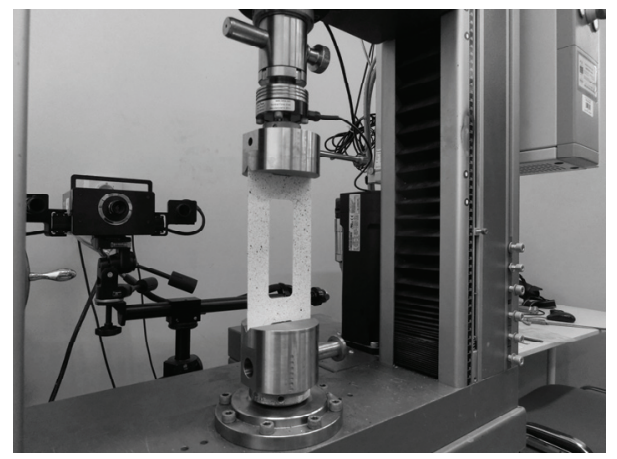

Fig. 3. Test stand used in experiment

In an experimental study of thin-walled structures, buckling is a very important detailed registration of the relevant test parameters. In order to adequately describe the critical and post-critical state of structures, it is necessary to register the load and displacement at selected points of the structure. In the context of the carried out of studies, the plate deflection used in the ARAMIS noncontact system was to measured, whose operating principle is based on stereographic transformations $[13,18]$. During the measurements the duration of the measurement, the compression force of the sample, cross-bar displacement, and deflection of the sample were recorded. As a result we have obtained measurements on the basis of which plate characteristics for assessing "critical state" were determined. The experimental tests enabled us to determine post-critical equilibrium paths which were then used to determine an approximated value of the critical load using 2 independent approximation methods: the $P-w^{2}$ and $P-w^{3}$ methods. The determination of an approximate critical load is based on the diagram of the load in a function of the square difference in strains in case of the $P-w^{2}$ method, or in a function of cubic difference in strains in case of the $P-w^{3}$ method. Regarding the discussed methods, the post-critical equilibrium paths $P-w^{2}$ and $P-w^{3}$ are approximated by the linear function [17]. The critical load in both of methods is defined as the point of intersection between the determined approximation line and the vertical axis of the coordinate system of the diagram $P=f_{2}\left(\varepsilon_{1}\right.$ $\left.\varepsilon_{2}\right)^{2}$ and $P=f_{3}\left(\varepsilon_{1}-\varepsilon_{2}\right)^{3}$. The results obtained by approximation via the above methods are not always unequivocal. The degree of linearity of the approximated curve strongly depends on the range of data used for determining critical loads. In addition to this, the results significantly depend on the number of points with specified coordinates subjected to approximation. 
In this experiment, the correlation coefficient $R^{2}$ was the key factor describing the accuracy of approximation, whose value determined the level of convergence between the approximation function and the selected range of the approximated experimental curve. In the applied approximation processes for experimental post-critical equilibrium paths of the structure the minimum correlation coefficient was set $R^{2} \geq 0.95$.

\section{RESULTS OF THE NUMERICAL CALCULATIONS AND EXPERIMENTAL INVESTIGATIONS}

The experimental tests and numerical computations led to a determination of critical forces and post-critical equilibrium paths in a weakly post-critical range of a thin-walled plate under compression. The identification of the critical state of the tested element was carried out on the basis of the obtained form of buckling, which is the first form of loss of stability, and the corresponding value of the critical load. The designated experimentally critical value was the basis for verification of the results of FEM numerical calculations. The received lowest form of buckling of the tested composites plate is shown in Fig. 4 a,b.

Small increases in load amount can result in rapid destruction of the structure, and that is why in the second stage of the calculation, in order to ensure the stable plate work in the postcritical range constituting the solution of the nonlinear stability issue, plate work in the postcritical state was forced with a higher, flexural-torsional form of plate buckling Fig.4 c,d. In the experimental research the extortion of a higher form of buckling is initiated by the introduction of the deflection using a steel rod placed in the mid-plate height.

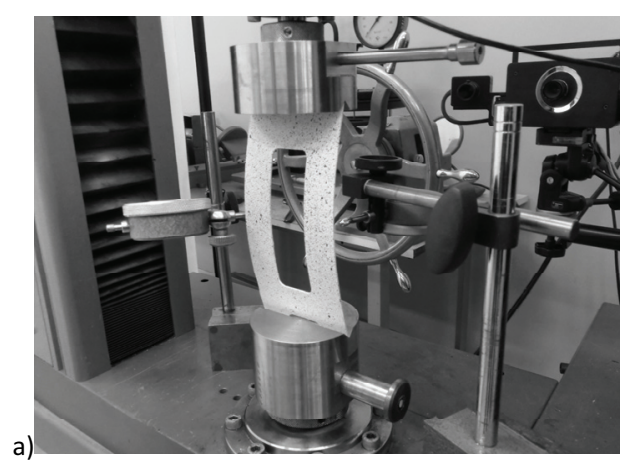

b)

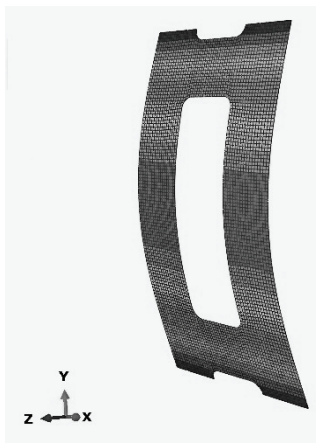



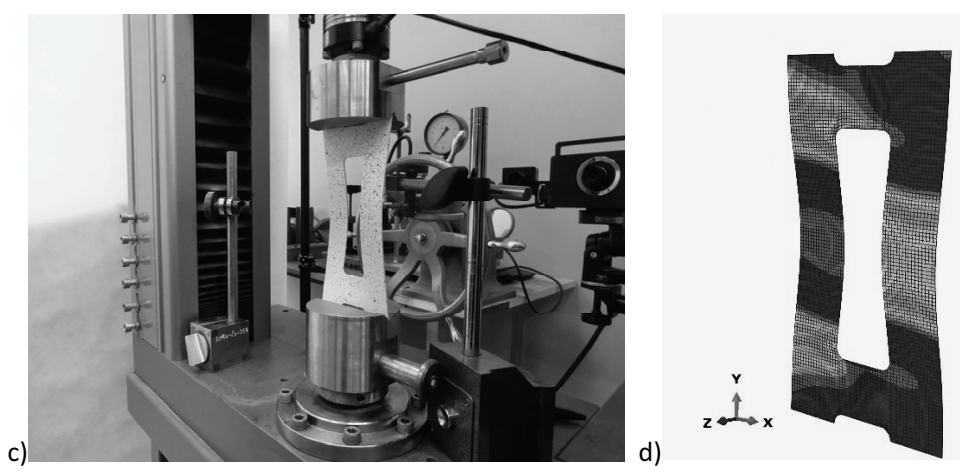

Fig. 4. The lowest $(a, b)$ and higher (stable) flexural-torsional form of plate buckling (c, d) received by experiment $(a, c)$ and FEM $(b, d)$

Approximation of the experimental curve applied in these cases is illustrated in Fig. 5.
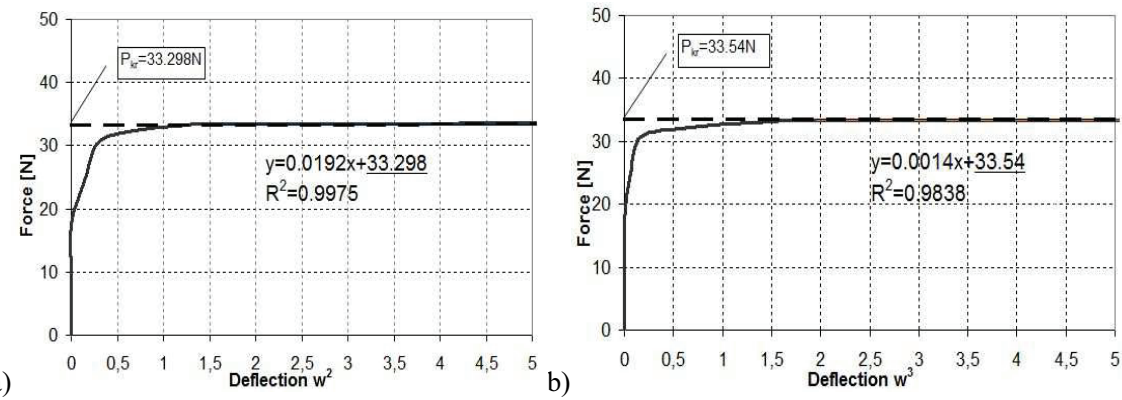

Fig. 5. Experimental results and approximation line used for determining critical load by:

a) $\mathrm{P}-\mathrm{w}^{2}$, b) $\mathrm{P}-\mathrm{w}^{3}$

The comparison of critical forces determined in the physical model with FEM results shown in Table 1. The errors values for the experimental critical loads are determined from the following dependence:

$$
\delta P_{c r}^{*}=\frac{\left|P_{c r}^{*}-P_{c r}\right|}{P_{c r}} 100 \%
$$

where: $P_{\text {cr }}^{*}$ is the experimental critical load and $P_{\mathrm{cr}}$ is the numerical bifurcation load determined by FEM 
Table 1. Comparison of experimental and numerical results of critical loads

\begin{tabular}{|c|c|c|c|c|}
\hline FEM & \multicolumn{2}{|c|}{$\mathrm{P}^{-w^{2}}$ method } & \multicolumn{2}{c|}{$\mathrm{P}^{-w^{3}}$ method } \\
\hline $\mathrm{P}_{\text {cr }}$ & $\mathrm{P}^{*}{ }_{\text {cr }}$ & $\delta \mathrm{P}^{*}{ }_{\text {cr }}$ & $\mathrm{P}_{\text {cr }}^{*}$ & $\delta \mathrm{P}^{*}{ }_{\text {cr }}$ \\
\hline$[\mathrm{N}]$ & {$[\mathrm{N}]$} & {$[\%]$} & {$[\mathrm{N}]$} & {$[\%]$} \\
\hline 36.74 & 33.30 & 9.37 & 33.54 & 8.71 \\
\hline
\end{tabular}

We herein observe that the results obtained with the $\mathrm{P}-\mathrm{w}^{2}$ and $\mathrm{P}-\mathrm{w}^{3}$ methods show very high agreement with the experimental and FEM numerical results. The highest differences do not exceed $10 \%$, which in the case of thin-walled structure stability analysis means that there is a high quantitative agreement between the applied research methods, and calculating the critical load of a real structure was correct.

In addition, we compared the post-critical equilibrium paths $P-U_{3}$ determined in the weak postcritical range. The paths given in Fig. 6 show less stiffness than the results of the numerical calculations, however, the maximum differences do not exceed $27 \%$. This fact results from the higher numerical model stiffness which preserves the ideal conditions of analysis, consistent with the results of similar studies published in existing literature [6,7].

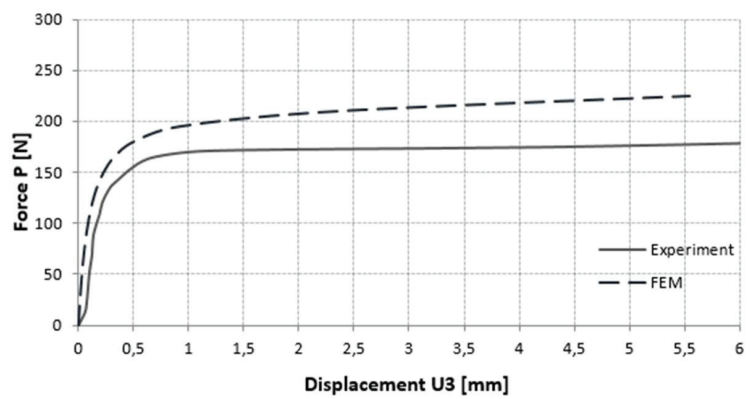

Fig. 6. Comparison of postcritical equlibrium paths

\section{CONCLUSiOnS}

The main aim of the investigations presented in this paper is to validate the numerical model using the results obtained during the experimental tests.

The results of the research make it possible to formulate the following conclusions:

- The results show a high agreement between the critical load results obtained with the approximation method - the difference does not exceed $10 \%$. 
- The postcritical equilibrium paths, both for the real structure and for the numerical model, retain the static character, confirming the validity of the adopted in the numerical calculation of the plate model.

- The resulting stable form of the real construction work corresponding to the higher, flexuraltorsional form of buckling indicates the possibility of using thin-walled plate elements with cut-outs as the elastic elements.

- Qualitative compatibility of the lowest form of buckling and the deformation form of the structure in the postcritical range was obtained, corresponding to forced work with a higher, flexural-torsional form.

- A good quantitative of compliance of the numerical analysis results with the experimental results confirm the adequacy of the developed numerical model, which in this case maps the behavior of real construction.

The research reported in this paper was conducted under the project UMO-2017/25/N/ST8/01066 financed by the National Science Centre Poland.

\section{REFERENCES}

1. Abaqus HTML Documentation, 2016.

2. Banat D, Mania R.J., "Comparison of failure criteria application for FML column buckling strength analysis", Composite Structures 140: 806-815, 2016, http://dx.doi.org/10.1016/j.compstruct.2016.01.024.

3. Campbell F.C. "Manufacturing Processes for Advanced Composites" Elsevier Ltd, 2004.

4. Dębski H.,"Experimental investigation post-buckling behaviour of composite column with top-hat cross section", Eksploatacja i Niezawodność - Maintenance and Reliability 2: 105-109, 2013.

5. Debski, H.; Sadowski, T., "Modelling of microcracks initiation and evolution along interfaces of the WC/Co composite by the finite element method:, COMPUTATIONAL MATERIALS SCIENCE 83: 403-411, 2014.

6. Falkowicz K., Debski H. "Postbuckling Behaviour of Laminated Plates with a Cut-Out", ADVANCES IN SCIENCE AND TECHNOLOGY RESEARCH JOURNAL 11(1): 186-193, 2017.

7. Falkowicz K., Debski H. "Numerical and Experimental Analysis of Compression Plate with Cut-Out", Mechanics and Mechanical Engineering 20(2): 167-175, 2016.

8. Falkowicz, K., Ferdynus, M., Dębski, H., "Numerical analysis of compressed plates with a cut-out operating in the geometrically nonlinear range", EKSPLOATACJA I NIEZAWODNOSC-MAINTENANCE AND RELIABILITY, 17(12): 222-235, 2015.

9. Falkowicz K., Mazurek P., Różyło P., Wysmulski P., Smagowski W., "Experimental and numerical analysis of the compression thin-walled composite plate", ADVANCES IN SCIENCE AND TECHNOLOGY RESEARCH JOURNAL 31(10): 177-184, 2016.

10. Falkowicz K., Ferdynus M., Wysmulski P., "FEM analysis of critical loads plate with cut-out", APPLIED COMPUTER SCIENCE 2(11):43-49, 2015.

11. Falkowicz K., Ferdynus M., Dębski H., "Numerical analysis of compressed plates with a cut-out operating in the geometrically nonlinear range", EKSPLOATACJA I NIEZAWODNOSC-MAINTENANCE AND RELIABILITY - 2015, 2(17): 222-227, 2015.

12. Jain, P., Kumar, A., "Postbuckling response of square laminates with a central circular cutout", Composite Structures, 65, p.179-185, 2004. 
13. Kahn-Jetter ZI., Chu TC., "Three-dimensional displacement measurements using digital image correlation and photogrammic analysis", Exp Mech 30(1):10-6, 1990.

14. Klepka, T.; Debski, H.; Rydarowski, H., "Characteristics of high-density polyethylene and its properties simulation with use of finite element method", POLIMERY 54(9): 668-672, 2009.

15. Kołakowski Z., Kowal-Michalska K., editors, "Selected problems of instabilities in composite structures", a series of monographs, Technical University of Lodz Press, 1999.

16. Kubiak T.,"Static and dynamic buckling of thin-walled plate structures", Springer, Verlag, London, 2013.

17. Kumar, D. and Singh, S. B., "Effects of boundary conditions on buckling and postbuckling responses of composite laminate with various shaped cutouts", Composites Structures, 92, p.769-779, 2010.

18. Luo PF, Chao YJ, Sutton MA, Peters III WH, "Accurate measurement of three-dimensional deformations in deformalble and rigid bodies using computer vision", Exp Mech 33(2):123-32, 1993.

19. Mason K. Autoclave Quality Outside The Autoclave?, High Performance Composites 3/1/2006.

20. Paszkiewicz M., Kubiak T., "Selected problems concerning determination of the buckling load of channel section beams and columns", Thin-Walled Structures, vol. 93, p.112-121, 2015.

21. Rozylo P., Wrzesinska K., „Numerical analysis of the behavior of compressed thin-walled elements with holes”, Advances in Science and Technology Research Journal 10(31): 199-206, 2016.

22. Rudawska, A.,Debski, H.,"EXPERIMENTAL AND NUMERICAL ANALYSIS OF ADHESIVELY BONDED ALUMINIUM ALLOY SHEETS JOINTS EKSPLOATACJA I NIEZAWODNOSC-MAINTENANCE AND RELIABILITY 1: 4-10, 2011.

23. Shah A.A, Ribakov Y., "Recent trends in steel fibered hihg-strenght concrete", Mater Des 32:4122-51, 2011.

24. Sobczyk B., Miskiewicz M." FRP laminates in construction - material characteristics and design aspects", Building Materials (in polish) 4 (512): 74-75, 2015.

25. Timoshenko S., Woinowsky-Krieger S., "Theory of plates and shells", McGraw-Hill, New York, 1959.

26. Rozylo P., Teter A., Dębski H., Wysmulski P., Falkowicz K., "Experimental and Numerical Study of the Buckling of Composite Profiles with Open Cross Section under Axial Compression”, Applied Composite Material 24(5): 1251-1264, 2017.

27. Zangenberg J., Brondsted P., Koefoed M., "Design of a fibrous composite preform for wind turbine rotor blades", Mater Des 56:635-41, 2014. 


\title{
LIST OF FIGURES AND TABLES
}

Fig. 1. Thin-walled plate: a) geometric model, b) physical model

Rys. 1. Płyta cienkościenna: a) model geometryczny, b) model fizyczny

Fig. 2. Discrete model of a composite plate a) boundary conditions, b) discretization of the geometric model Rys. 2. Model dyskretny kompozytowej płyty a) warunki brzegowe, b) model zdyskretyzowany

Fig. 3. Test stand used in experiment

Rys.3. Stanowisko do badań eksperymentalnych

Fig. 4. The lowest $(a, b)$ and higher (stable) flexural-torsional form of plate buckling $(c, d)$ received by experiment $(a, c)$ and FEM $(b, d)$

Rys.4. Najniższa (a,b ) i wyższa (stabilna) giętno-skrętna postać wyboczenia płyty (c, d) otrzymana w eksperymencie (a, c) i w badaniach numerycznych (b, d)

Fig. 5. Experimental results and approximation line used for determining critical load by a) $\left.\mathrm{P}-\mathrm{w}^{2}, \mathrm{~b}\right) \mathrm{P}-\mathrm{w}^{3}$ Rys.5. Wyniki eksperymentalne i wyznaczone siły krytyczne za pomocą metod aproksymacyjnych:

a) $\mathrm{P}-\mathrm{w}^{2}$, b) $\mathrm{P}-\mathrm{w}^{3}$

Fig. 6. Comparison of postcritical equlibrium paths

Rys.6. Zestawienie pokrytycznych ścieżek równowagi

Tab. 1. Comparison of experimental and numerical results of critical loads

Tab. 1. Porównanie eksperymentalnych i numerycznych wyników siły krytycznej

Received 31.01.2017

Revised 06.02.2018

\section{DOŚWIADCZALNO - NUMERYCZNA ANALIZA ŚCISKANEJ CIENKOŚCIENNEJ PLYTY KOMPOZYTOWEJ OSLABIONEJ OTWOREM}

\author{
Keywords: struktury cienkościenne, siła krytyczna, analiza nieliniowa, kompozyty, badania eksperymentalne, MES, analiza \\ numeryczna, płyta z wycięciem
}

\section{SUMMARY:}

W pracy zajmowano się oryginalną koncepcją płytowego elementu cienkościennego z centralnym wycięciem, do zastosowania jako element sprężysty. Badania obejmowały liniową i nieliniową analizę numeryczną konstrukcji z wykorzystaniem metody elementów skończonych oraz eksperymentalną weryfikację obliczeń MES.

Przedmiot badań stanowiła cienkościenna płyta $\mathrm{z}$ centralnym prostokątnym wycięciem, wykonana z kompozytu węglowo-epoksydowego. Struktura laminatu złożona była z 8 warstw o jednakowej grubości wynoszącej $0.131[\mathrm{~mm}]$ w symetrycznym układzie warstw względem płaszczyzny środkowej pakietu. Badania prowadzono na płycie kompozytowej o konfiguracji warstw kompozytu [90/-45/45/0]s. 
Zakres pracy obejmował badania eksperymentalne na rzeczywistej konstrukcji oraz wykonanie symulacji numerycznej z wykorzystaniem metody elementów skończonych. Analizowano stan krytyczny ściskanej osiowo cienkościennej płyty kompozytowej z centralnym prostokątnym wycięciem, podpartej przegubowo na obydwu końcach oraz rozwiązanie zagadnienia nieliniowej stateczności, w którym obliczenia prowadzono na modelach z zainicjowaną imperfekcją geometryczną odpowiadającą wyższej, giętno- skrętnej postaci wyboczenia konstrukcji.

Prowadzone badania eksperymentalne na wytworzonej cienkościennej płycie kompozytowej umożliwiły obserwację rzeczywistego zachowania się konstrukcji w stanie krytycznym i pokrytycznym, umożliwiając jednocześnie identyfikację postaci wyboczenia oraz określenie wartości obciążenia krytycznego. Prowadzone równolegle symulacje numeryczne miały na celu opracowanie adekwatnych modeli MES zweryfikowanych doświadczalnie, umożliwiających modelowanie zagadnienia stateczności kompozytowych konstrukcji cienkościennych, w wierny sposób odwzorowujących zachowanie konstrukcji rzeczywistej. Zastosowanym narzędziem numerycznym był program Abaqus, natomiast badania doświadczalne ściskanej płyty prowadzono na uniwersalnej maszynie wytrzymałościowej Zwick/Roell Z050.

Przeprowadzone badania doświadczalne ściskanej płyty kompozytowej z wycięciem dostarczyły informacji pozwalających na ocenę stanu odkształcenia konstrukcji rzeczywistej w funkcji obciążenia zewnętrznego. Otrzymane wyniki badań umożliwiły dokonanie jakościowej i ilościowej analizy stanu dokrytycznego oraz krytycznego w oparciu o zarejestrowane parametry próby. Identyfikację stanu krytycznego badanego elementu przeprowadzono na podstawie uzyskanej formy wyboczenia stanowiącej pierwszą postać utraty stateczności oraz odpowiadającej jej wartości obciążenia krytycznego. Na podstawie przeprowadzonych w badaniach eksperymentalnych pomiarów odkształceń w funkcji obciążenia zewnętrznego określone zostały średnie wartości siły krytycznej dla analizowanej płyty z wykorzystaniem dwóch aproksymacyjnych metod: $\mathrm{P}-\mathrm{w}^{2}$ i $\mathrm{P}-\mathrm{w}^{3}$, które następnie zestawiono z wynikami obliczeń numerycznych MES.

W drugim etapie obliczeń, stanowiącym rozwiązanie zagadnienia nieliniowej stateczności analizowano pracę płyty W stanie pokrytycznym z wymuszoną wyższą, giętno-skrętną postacią wyboczenia płyty. W trakcie obciążania konstrukcji w zakresie pokrytycznym rejestrowano te same parametry próby co w zakresie krytycznym. Wyznaczone zostały pokrytyczne ścieżki równowagi w formie wykresów siła-ugięcie $\left(\mathrm{P}-\mathrm{U}_{3}\right)$, umożliwiające określenie charakterystyki badanej płyty w stanie pokrytycznym.

Reasumując, przedstawione w pracy wyniki obliczeń numerycznych MES zostały pomyślnie zweryfikowane poprzez wyniki badań doświadczalnych. Otrzymane wyniki badań korespondują z wynikami obliczeń numerycznych, czego wyrazem jest wysoka zbieżność wyników nie przekraczająca $10 \%$.

Pokrytyczne ścieżki równowagi dla konstrukcji rzeczywistej oraz modelu numerycznego zachowują charakter stateczny, potwierdzając zasadność przyjętego w obliczeniach numerycznych płytowego modelu konstrukcji, umożliwiającego opis zagadnienia nieliniowej stateczności. Otrzymana w przypadku konstrukcji rzeczywistej stabilna postać pracy, odpowiadająca wyższej, giętno-skrętnej postaci wyboczenia wskazuje na możliwość wykorzystania cienkościennych elementów płytowych z wycięciem do zastosowań, jako elementy sprężyste.

W prowadzonych badaniach otrzymano jakościową zgodność najniższej postaci wyboczenia oraz formy deformacji konstrukcji w zakresie pokrytycznym, odpowiadających wymuszeniu pracy z wyższą postacią o charakterze giętnoskrętnym. Jednocześnie zadawalająca zgodność ilościowa wyników analizy numerycznej z wynikami badań doświadczalnych potwierdza adekwatność opracowanego modelu numerycznego, który w analizowanym przypadku odwzorowuje zachowanie rzeczywistej konstrukcji. 